(Zurich) on digitalis as a panacea, a conception that spread to the Continent from England via Göttingen. Dr. Lichtenthaeler (Leysin) continued his contributions to the study of Hippocratic medicine. Dr. J. Kurmann (Liebefeld-Berne) spoke on a little-known mineralogist, von Wartensee, of Lucerne (1750-84), and also on theories and controversies of 1874-1909 over the ripening of hard cheese. The beginnings of industrial medicine were touched on by Prof. $\mathbf{H}$. Buess (Basle) in his talk on F. A. Roeber (17651827).

A symposium, which could have been related to the central theme of the session, on "Form- und Musterbindung bei Tieren", was organized by the Zoological Section under Prof. M. Lüscher (Bern) as president. But after the general introduction by $\mathrm{A}$. Portmann (Basle), only very special points were discussed, including the effects of reaggregation of cellmixtures of Drosophila, by the chairman, Prof. E. Hadorn (Zurich), the standpoint of evolutionary physiology, by Prof. F. E. Lehmann (Berne), and the formative function of competition and inhibition for invertebrates, by Dr. P. Tardent (Naples), who also gave a short separate paper on the action of dinitrophenol on the regeneration of Tubularia, in the afternoon session under Prof. Rosin (Berne). This session included a film on the behaviour of herds of deer, and concluded, in association with the Genetic Section, with two major lectures, by Prof. J. Brachet (Brussels), on "Le role des acides nucléiques dans le transfer de l'information génétique", and Dr. F. Vogel (Berlin), on "Die spontane Mutabilität menschlicher Gene", under the chairmanship of Dr. E.
Oehler (Lausanne). Both gave an account of the latest state of their subject and showed many problems still unsolved.

A symposium arranged by the Section for Logic and Philosophy of Science on "Reiz und Empfindung" unfortunately clashed with the preceding. The programme was: "Prof. S. Weidmann (University of Berne), "Physiologie der Sinnesorgane"; Prof. H. König (director, Federal Office of Weights and Measures, Berne), "Messungsprobleme von Farbenreiz und Farbenempfindung"; Prof. K. Miescher (Colorimetry Laboratory, University of Basle), "Zweierlei Metrik in der Beziehung Farbe-Reiz"; Prof. F. Gonseth (Lausanne), "Erkenntnistheoretisches über Reiz und Empfindung"; discussion led by Prof. R. Meyer (University of Zurich).

Nothing outstanding has to be reported of the three remaining Sections (Mineralogy and Petrography, Palæontology, Botany). Between ten and fifteen shorter communications were scheduled for each, and excursions led by Prof. E. Niggli (Berne) to the Grimsel region and by E. Berger (Biel) to the nature reserve in the Freibergen.

Once again a fascinating unscheduled tailpiece was provided for foreign participants at the gateway of Switzerland, Basle: the spectacular Trachtenfest, breaking up on the same day, filled the streets and station to the echoing of yodel, horn and drum with its extraordinary multiplicity of meticulously recon. structed costumes from country, town and village of Switzerland, gracefully and picturesquely worn, a display of joyful colour, art and national piety not easily matched elsewhere.

\title{
THE SCIENCE ASSOCIATION OF NIGERIA
}

$\mathrm{T}$ HE fourth annual conference of the Science Association of Nigeria, held at Enugu during December 14-18, 1961, showed clearly that this young and vigorous Association is fulfilling a need. There were about 180 registered conference members, and about twice this number attended the opening ceremony at which Dr. M. I. Okpara, Premier of Eastern Nigeria, in an inspiring oration, showed what an important part science has to play in the development of Nigeria. This point was also emphas. ized by the 1961 president of the Association, Dr. J. C. Edozien, professor of chemical pathology at University College, Ibadan. It is not, he said, simply a matter of applying known scientific methods and technology to Nigerian problems, but also of pursuing, in Nigeria, original research on a host of new problems and on many old problems which are as yet unsolved.

The Science Association of Nigeria was also fortunate to have Sir Julian Huxley as a guest speaker. In a lecture after the opening ceremony, he traced the advances in scientific knowledge which followed Darwin's theory of evolution. This emphasis on evolution was most relevant to scientists working in this rapidly developing country. Indeed, Sir Julian observed that West Africa now is developing at a speed unprecedented in the world's history.

The Association has members of many disciplines, and the annual conference provides an excellent opportunity for them to hear up-to-date reviews of various branches of science. Although the number of scientists in Nigeria is rapidly increasing, it is still quite small, and the stimulus of these fairly general conferences is considerable. An encouraging feature of Nigerian science is the co-operation between scientists of different disciplines, which often leads to real advances in knowledge.

The highlight of the conference was a symposium on protein. Under the chairmanship of Prof. Eni $\mathrm{Njoku}$, medical doctors, chemists and agriculturists contributed short papers which were followed by a stimulating discussion. Dr. J. G. Beetlestone spoke about the chemical composition of protein; Prof. J. C. Edozien, Dr. W. R. F. Collis, Dr. J. WatsonWilliams and Dr. E. M. Poulton spoke about protein deficiency, which is still very serious in most Nigerian children, even in apparently prosperous villages; Prof. V. A. Oyenuga, Dr. W. R. Stanton, Dr. S. G. Wilson and Mr. J. A. Akinrele gave papers on the production of protein in animal and vegetable foodstuffs.

Some people have commented on the strong representation of agriculturists and medical men in the Science Association of Nigeria, but this is surely quite appropriate in a country where improvements in diet and health are of such crucial importance to the welfare of the rapidly growing people and their progress in the modern world. The physical, chemical and industrial aspects of science are not, however, being overlooked and "The Place of Science in the Industrial Development of Nigeria" has been chosen for the theme of the next annual conference, due to be held at Lagos in December 1962.

At the annual general meeting, Mr. R. W. J. Keay was elected president for the year 1961-62, and Dr. C. I. O. Olaniyan was elected honorary secretary. 